UDC 330.34:339.17

JEL Classification: D81; L22; M21; O11

LOI Anna,

Postgraduate at the Department of Economics and Business Finance Kyiv National University of Trade and Economics 19, Kyoto str., Kyiv, 02156, Ukraine

E-mail:a.loi@knute.edu.ua

ORCID: 0000-0002-4092-887X
DOI: http://doi.org/10.31617/visnik.knute.2021(140)06

BLAKYTA Hanna,

DSc (Economics), Professor, Head of the Department of Economics and Business Finance Kyiv National University of Trade and Economics 19, Kyoto str., Kyiv, 02156, Ukraine

E-mail: g.blakyta@knute.edu.ua ORCID: 0000-0001-7843-7120

\title{
ECONOMIC POTENTIAL OF THE TRADE ENTERPRISE: STRUCTURAL ASPECT
}

The main approaches to the classification of influencing factors of the enterprise are studied in this article. The most important types of factors that affect the activities of the enterprise are identified. The existing approaches are fully systematized. The authors offer their vision of the environment of interrelation of the main influencing factors on the economic potential.

Keywords: factors, classification of factors, enterprise, economic potential.

Background. The economic potential of the enterprise is a complex system of elements that are inextricably linked with each other, with environmental conditions, certain internal features and the general condition of the enterprise. Therefore, it is important to identify and assess the impact of factors on the development of economic potential, which will create a mechanism for adaptation to both negative and positive factors for the environment of the enterprise. After all, the identification and analysis of factors are the basis of effective risk management of the enterprise. They help to ensure the stability of the enterprise, and identify development opportunities.

Analysis of recent research and publications. Many scientists have been devoted their work to the issue of determining the influence of various factors of the enterprise, for example, K. Vaskivska, L. Lozinska, Yu. Galimuk, O. Yemelyanov, O. Kurinna, Ja. Sekirozh, I. Nagorna, O. Bezruchko [1-6] and others. Because the set of factors for each enterprise is unique. They can be differently classified, structured, and evaluated. This is due to the diversity of scientific views.

The aim of the article is to study and systematize approaches to the classification of influencing factors on the economic potential of the enterprise.

(C) Loi A., Blakyta H., 2021 
Materials and methods. The information base of the study is scientific articles, monographs, thesis and other works, which identify the influencing factors of the company and its economic potential. During the study, methods of analysis and synthesis, generalization, comparison were used, which systematized the main scientific approaches to the classification of influencing factors on the economic potential of the enterprise.

Results. The most common classification of factors in the scientific literature is their division into factors of internal and external environments. But each scientist has his vision of their content and characteristics. Most authors who use this classification, include everything related to the activities of the state and society, their impact on the activities of enterprises and market conditions to the factors of the external environment. Everything related to the activities of the enterprise and regulated by the enterprise is internal [1-3; 7-10].

N. Kashchena and J. Sekirozh have a similar view, proposing to divide the influencing factors of the enterprise into exogenous (external, independent on the enterprise) and endogenous (internal, dependent on the enterprise). Exogenous include general economic, market external and others. While endogenous are organizational, production and technological, financial and economic, social, market internal and investment factors [4, p. 254; 11, p. 272].

Other authors suggest additional structuring of internal and external factors. Thus, there is a division of external factors into factors of micro and macro environments. The factors of the micro environment include the competitive environment, prices, solvency of market participants and others. The factors of the macro environment are known as political, economic, legal, demographic, cultural, technological and natural geographical $[12$, p. $30 ; 13$, p. $50 ; 14$, p. 296]. However, there is another opinion, according to which micro level factors are factors of the internal environment, and macro level is external $[5$, p. $55 ; 15$, p. $34 ; 16$, p. 44]. O. Bezruchko also adheres to this position and complements this classification with episodic factors characterized by inconsistency, spontaneity, low level of predictability. They can be both external (natural disasters, wars, terrorist attacks, raids, etc.) and internal (accidents at the enterprise, equipment failure, financial crisis, etc.) [6, p. 104; 15, p. 34].

M. Chorna and S. Glukhova also single out the meso level, namely branch factors [16, p. 45], which is quite appropriate. It is the division of micro level (internal environment), meso level (external environment, industry), and macro level (external environment, state) that should be used to classify factors of economic potential. As it allows to characterize all levels of enterprise more effectively, to reflect the specifics of the individual enterprise.

One of the methods of assessing the external environment is PESTanalysis, based on the study of environmental changes in four areas: political, economic, social and technological. There are similar PESTLE-analysis, which contains two more directions as legal and environmental, and 
PESTLIED with international and demographic [17, p. 35]. This technique is taken as a basis by some scientists in determining the factors of influence and adapted by them following the selected objects of study. In particular, N. Kasyanov and others distinguish economic, social, political factors, but instead of technological they distinguish legal $[9$, p. 38]. However, D. Vasylkivsky shows intellectual and cultural factors [18, p. 151].

I. Nagorna adds financial and demographic factors to the basic grouping (where there are political, social, economic, technological) [5, p. 56]. Although some scientists define the demographic factor as a component of social ones $[19$, p. $39 ; 20$, p. $80 ; 21$, p. 23], which is quite correct to our point of view.

S. Bonyar and O. Alyabieva add marketing factors and additionally divide them into quantitative and qualitative [20, p. 80]. L. Gerbych, L. Netrebchuk underline economic, political, socio-demographic, naturalclimatic, and ecological factors [22, p. 95]. V. Korsak supplemented this list with the following groups of factors: financial, demographic, consumer, institutional, urban planning, innovation, geographical and natural, and intraindustry [23, c. 49]. After analyzing the views of the definition of the elements of this classification (Figure 1), we can say that economic factors are fundamental and must be taken into account and analyzed by the enterprise.

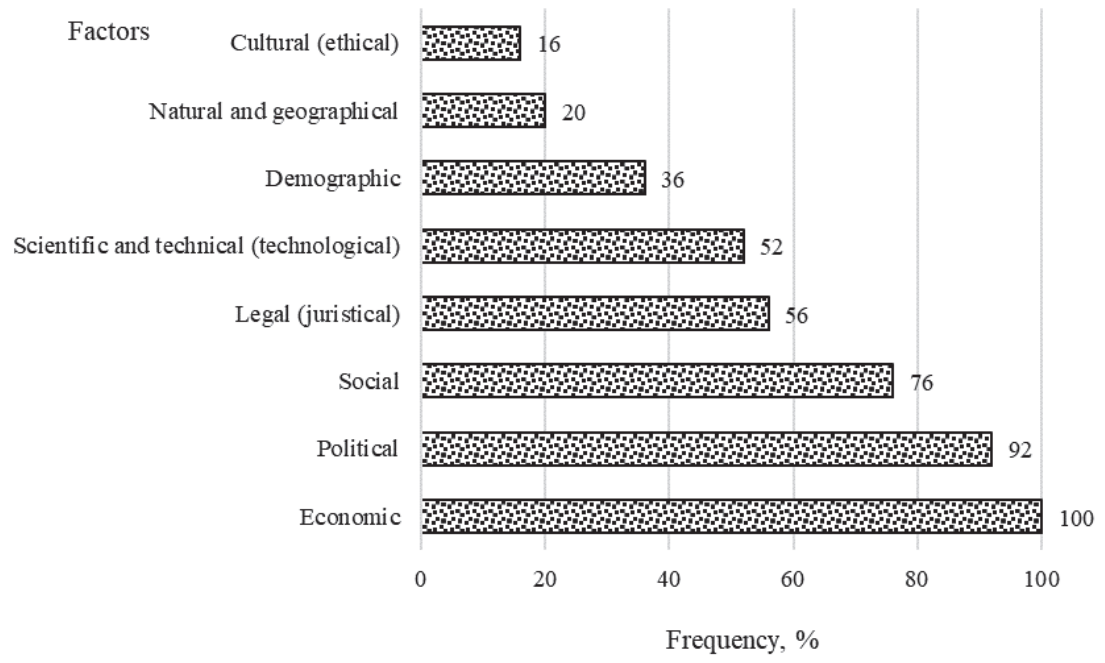

Figure 1. The frequency of mentions of types of influencing factors in the scientific literature

Source: based on [1-25].

Regarding the definition of other types of factors, this classification is quite variable and may vary depending on which area of activity the company belongs to. Therefore, we propose to determine the following classification of influencing factors on the economic potential of trade: economic, social (including demographic), political and legal, scientific and technical (technological, innovative), natural and geographical. The location of the enterprise and the development of the region are also very important influencing 
factors on the economic potential of the trade enterprise (TE). A detailed list of possible external influencing factors on the economic potential of TE is presented in the Table 1. However, it is not final and may be reduced or supplemented depending on the management policy and strategy of the enterprise and the assessment of the degree of influence of each factors, identifying only the most significant of them.

Table 1

\section{Classification of external influencing factors on the economic potential of the enterprise of trade by types}

\begin{tabular}{|c|c|}
\hline Classification feature & Factors \\
\hline Economic & $\begin{array}{l}\text { Stage of the life cycle of the socio-economic system } \\
\text { GDP dynamics } \\
\text { Financial condition of the state } \\
\text { Budget deficit } \\
\text { Inflation rate } \\
\text { Fluctuations in the national currency } \\
\text { Discount rate of the National Bank } \\
\text { The level of tax burden }\end{array}$ \\
\hline Political & $\begin{array}{l}\text { Political stability / instability } \\
\text { The state of progress of economic reforms } \\
\text { Economic, financial, tax policy } \\
\text { The level of corruption } \\
\text { Strategy of foreign economic relations }\end{array}$ \\
\hline Social & $\begin{array}{l}\text { Dynamics of the number, density and structure of the population } \\
\text { of the state and region } \\
\text { Migration trends } \\
\text { Unemployment rate } \\
\text { Depth of stratification of society } \\
\text { Level of education of the population } \\
\text { Consumer moods, habits, traditions, consumption norms, fashion trends }\end{array}$ \\
\hline Legal & $\begin{array}{l}\text { The level of stability of legislation } \\
\text { The complexity of licensing and patenting mechanisms } \\
\text { Perfection of the regulatory framework } \\
\text { The level of compliance with the law } \\
\text { Activities of the judiciary, prosecutor's office, law enforcement } \\
\text { agencies, justice, arbitration } \\
\text { Protection of competition, property rights, including intellectual } \\
\text { property rights }\end{array}$ \\
\hline $\begin{array}{l}\text { Scientific } \\
\text { and technical }\end{array}$ & $\begin{array}{l}\text { Investment and innovation climate } \\
\text { The level of public funding for new developments } \\
\text { The level of technology development and their competitiveness } \\
\text { in the international market } \\
\text { Scientific and technological progress }\end{array}$ \\
\hline $\begin{array}{l}\text { Natural and } \\
\text { geographical }\end{array}$ & $\begin{array}{l}\text { Infrastructure development in the country and the region } \\
\text { The state of the transport network } \\
\text { Availability / remoteness of alternative resources, suppliers, etc. }\end{array}$ \\
\hline
\end{tabular}

Source: $[1-6 ; 12 ; 13 ; 15 ; 16 ; 19 ; 21 ; 24 ; 25]$.

In addition to these, there are many other signs of grouping factors that affect the economic potential. We distinguish:

terms of validity - short-term (valid for up to one year) and long-term (valid for more than one year) [2, p. 95]; or permanent and temporary [4, p. 254]; types of economic resources - material, labor, technical, financial and information resources of the enterprise [2, p. 95]; 
the nature of the impact - extensive (due to the growth of the relevant types of resources of the enterprise) and intensive (due to the quality improvement of the relevant types of resources of the enterprise) [2, p. 95];

degree of influence - primary and secondary [4, p. 254] or generalizing (basic), derived and detailed [5, p. 75];

method of influence - factors of direct and indirect influence [2, p. 95; 13, p. 50];

level of influence - factors of the first, second and third levels. In this case, the first level includes priority factors (consumers). The factors of the second level should include other factors of direct influence (suppliers, competitors, financial institutions, etc.). And the factors of the third level are factors of indirect influence [13, p. 50];

degree of generalization - criterion, key, basic [2, p. 169];

change (immutability) during a certain period - static, dynamic [2, p. 104]; the ability to control factors - controlled, conditionally controlled, uncontrolled [2, p. 104; 22, p. 94];

definition - potential; actual [4, p. 254];

degree of interdependence - independent is determined by certain events or trends; derived is the result of independent factors as the action of causation [4, p. 254];

method of evaluation - quantitative, which can be quantified; qualitative, which is difficult to quantify, and therefore they are measured using qualitative scales [2, p. 109; 22, p. 94].

N. Kasyanova and others note that quantitative factors have an extensive (their impact can be represented as the sum of the corresponding increments) and intensive (the result of the impact is determined by changing the coefficients) nature $[9$, p. 221].

Summing up, we propose the classification of influencing factors on the economic potential of TE (Table 2) and determine the environment of their relationship (Figure 2).

Table 2

Classification of influencing factors on the economic potential of the trade enterprise

\begin{tabular}{|c|c|}
\hline Classification feature & Group of factors \\
\hline By its content & $\begin{array}{l}\text { External } \\
\text { Internal }\end{array}$ \\
\hline By level of occurrence & $\begin{array}{l}\text { Individual * } \\
\text { Local * } \\
\text { General * } \\
\text { Global * }\end{array}$ \\
\hline By level of influence & $\begin{array}{l}\text { Direct influence } \\
\text { Conditionally direct influence } \\
\text { Indirect influence }\end{array}$ \\
\hline By the degree of controllability & $\begin{array}{l}\text { Managed } \\
\text { Conditionally managed } \\
\text { Unmanaged }\end{array}$ \\
\hline
\end{tabular}

* Proposed by the authors.

Source: supplemented by authors $[1-3 ; 5-7 ; 13 ; 22]$. 


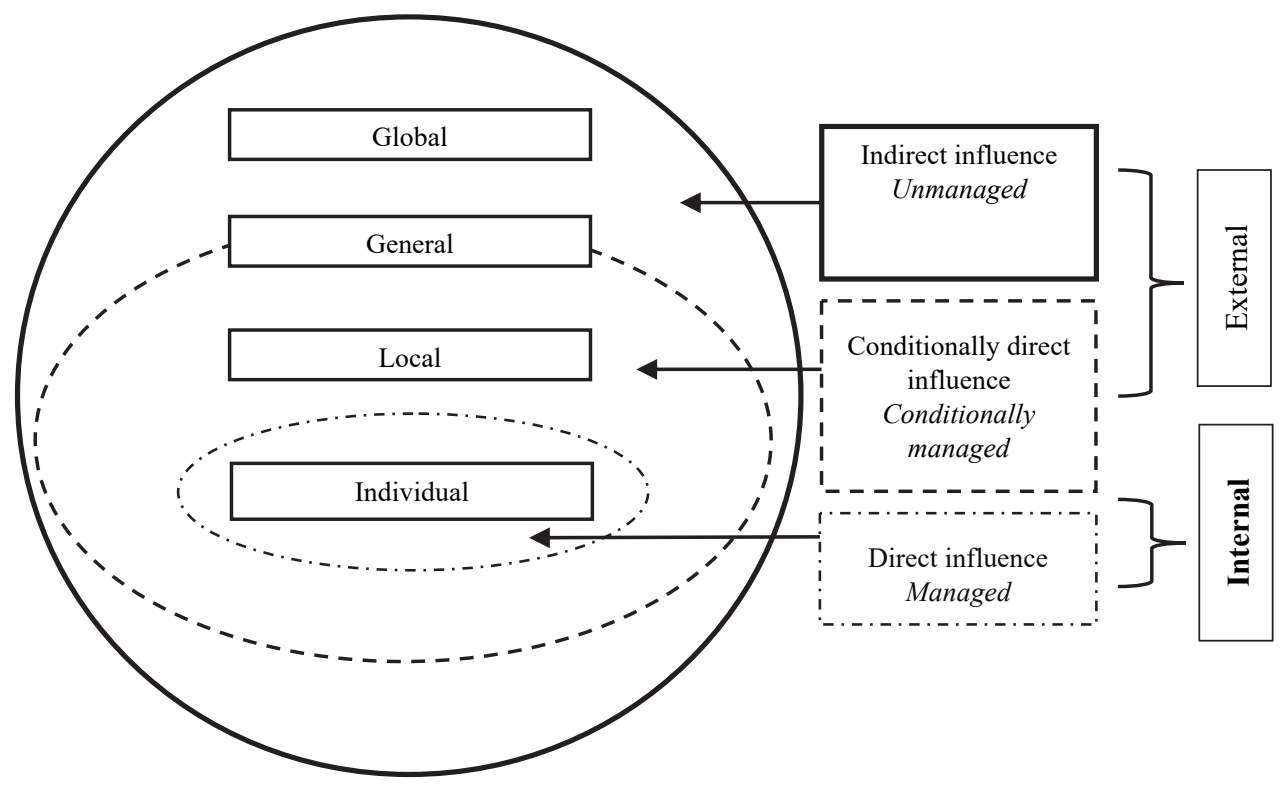

Figure 2. The environment of interaction of influencing factors on the economic potential of the trade enterprise

Source: proposed by the authors.

All factors of influence we divide into internal and external (Figure 2). Internal factors include individual or micro economic, which directly affect the economic potential of the enterprise. They are created and regulated by the enterprise. External factors are local, i.e. sectoral factors (meso economic), which can directly affect the activities of the enterprise. They are conditionally controlled because the enterprise is an integral part of the industry and its activities affect others and create conditions for the development of its activities. Also, external factors include general, i.e. the influence of the state on the enterprise (macro economic), which depending on the specific factor can have both direct (tax policy of the state) and indirect (mostly) influence on the economic potential of the enterprise. They are uncontrolled by the enterprise. Global factors affect the activities of the state and may have some impact on the activities of the enterprise and its economic potential.

Conclusion. The fundamental place among the factors of the external environment is occupied by economic factors. Other types should be determined and taken into account depending on the significance of their impact and the specifics of the activity.

A single factor can be classified on different grounds. It is a unifying element between different classifications. So it is proposed to reflect the specifics of their relationship and determine the environment of the interaction of influencing factors on the economic potential of trade. This can help to establish the place of the factor in the overall system, which will facilitate the process of assessing the degree of influencing factors on the economic potential of the enterprise. 
It also presents its vision of structuring factors depending on the level of occurrence: individual, local, general, global. Determining the factors according to this classification makes it possible to rank the degree of influence of external factors, because the lower the level of occurrence is, the more factor affects the economic potential of the enterprise.

\section{REFERENCES}

1. Vaskivska, K. V., Lozinska, L. D., \& Halimuk, Yu. O. (2020). Ekonomichnyi potentsial pidpryiemstva $\mathrm{v}$ umovakh zmin: sut ta kharakterni osoblyvosti [Economic potential of the enterprise in the conditions of changes: essence and characteristic features]. Efektyvna ekonomika - Efficient economy, 5. Retrieved from $\mathrm{http}: / / w w w . e c o n o m y . n a y k a . c o m . u a / p d f / 5 \_2020 / 9 . p d f$ [in Ukrainian].

2. Iemelianov, O. Yu. (2019). Instrumentarii ta modeli otsiniuvannia potentsialu ekonomichnoho rozvytku pidpryiemstv [Tools and models for assessing the potential of economic development of enterprises]. Doctor's thesis. Lviv [in Ukrainian].

3. Kurinna, O. V. (2014). Teoretychni aspekty upravlinnia finansovym potentsialom pidpryiemstv [Theoretical aspects of managing the financial potential of enterprises]. Naukovyi visnyk Akademii munitsypalnoho upravlinnia. - Scientific Bulletin of the Academy of Municipal Administration, 1, 161-171 [in Ukrainian].

4. Sekirozh, Ya. V. (2020). Klasyfikatsiia faktoriv vplyvu na riven innovatsiinoho zabezpechennia stiikoho rozvytku pidpryiemstv [Classification of factors influencing the level of innovative support for sustainable development of enterprises]. Biznes Inform - Business Inform, 11, 249-256 [in Ukrainian].

5. Nahorna, I. V. (2019) Oblikovo-analitychne zabezpechennia upravlinnia finansovoiu stiikistiu pidpryiemstv torhivli [Accounting and analytical support for managing the financial stability of trade enterprises]. Candidate's thesis. Kharkiv: KhDUKhT [in Ukrainian].

6. Bezruchko, O. O. (2014). Osoblyvosti upravlinnia ekonomichnym potentsialom pidpryiemstva $\mathrm{v}$ umovakh minlyvoho zovnishnoho seredovyshcha [Features of managing the economic potential of the enterprise in a changing environment]. Visnyk Kremenchutskoho natsionalnoho universytetu imeni Mykhaila Ostrohradskoho - Bulletin of Kremenchuk Mykhailo Ostrohradsky National University, 1, 96-107 [in Ukrainian].

7. Arefieva, O. V., Andriienko, M. M., \& Kravchenko, O. R. (2018). Upravlinnia finansovym potentsialom pidpryiemstva [Financial potential management of the enterprise]. Ekonomika i suspilstvo - Economy and society, 18, 252-257 [in Ukrainian].

8. Hrytsulenko, S. I. (2014). Potentsial i rozvytok pidpryiemstva [Potential and development of the enterprise]. Odesa. ONAZ im. O.S. Popova [in Ukrainian].

9. Kasianova, N. V., Solokha, D. V., Moreva, V. V., Bieliakova, O. V., \& Balakai, O. B. (2012). Potentsial pidpryiemstva: formuvannia ta vykorystannia [Enterprise potential: formation and use]. Donetsk: Vyd-vo Tsyfrova typohrafiia [in Ukrainian].

10. Kovtunenko, Yu. V., Valyanskaya, A. O., \& Miroshnykova, K. O. (2017). Economic analysis and its importance in the management of enterprise. Economics: time realities, 1(29), 80-85. Retrieved from http://economics.opu.ua/files/archive/ 2017/No1/80.pdf [in English]. 
11. Kashchena, N. B. (2018). Formuvannia stratehichnykh oriientyriv zabezpechennia ekonomichnoi stiikosti pidpryiemstva $\mathrm{v}$ umovakh nevyznachenosti [The formulation of strategic guidelines to ensure the economic stability of enterprises in conditions of uncertainty]. Retrieved from https://elib.hduht.edu.ua/ bitstream/123456789/3283/1/\%d0\%9a\%d0\%b0\%d1\%89\%d0\%b5\%d0\%bd\%d0 \%b0.pdf [in Ukrainian].

12. Asaul, A. N., Voynarenko, M. P., Knyazev, S. Ya., \& Rzaeva, T. G. (2011). Proizvodstvenno-ekonomicheskiy potentsial i delovaya aktivnost sub'ektov predprinimatelskoy deyatelnosti [Production, economic potential and business activity of business entities]. SPb.: ANO IPEV [in Russian].

13. Vlasova, N. O., Chorna, M. V., \& Bieliaieva, M. V. (2013). Ekonomichnyi mekhanizm rehuliuvannia pidpryiemnytskoi diialnosti v rozdribnii torhivli [The economic mechanism for regulating business activities in retail trade]. Kharkiv: KhDUKhT [in Ukrainian].

14. Sycheva I. N., Ovchinnicov Y. L., Voronkova O. Yu. et al. (2018). Economic Potential and Development Prospects of Small Businesses in Rural Areas. European Research Studies Journal. Vol. XXI (4). (pp. 292-303). Retrieved from https://www.ersj.eu/dmdocuments/2018_XXI_4_23.pdf [in English].

15. Maslak, O. I., Kviatkovska, L. A., \& Bezruchko, O. O. (2012). Osoblyvosti formuvannia ekonomichnoho potentsialu pidpryiemstva $\mathrm{v}$ umovakh tsyklichnykh kolyvan [Features of formation of economic potential of the enterprise in the conditions of cyclic fluctuations]. Aktualni problemy ekonomiky - Current economic problems, 9, 36-46 [in Ukrainian].

16. Chorna, M. V., \& Hlukhova, S. V. (2012). Otsinka efektyvnosti innovatsiinoi diialnosti pidpryiemstv [Evaluation of the effectiveness of innovative activities of enterprises]. Kharkiv: KhDUKhT [in Ukrainian].

17. Kovbasiuk, Yu. V., \& Hoshovska, V. A. (2015). Stratehichni priorytety rozvytku Ukrainy [Strategic priorities of Ukraine's development]. Kyiv: NADU [in Ukrainian].

18. Vasylkivskyi, D. M. (2015). Formuvannia ta realizatsiia mekhanizmu pidvyshchennia ekonomichnoho potentsialu pidpryiemstva [Formation and implementation of the mechanism of increase of economic potential of the enterprise]. Doctor's thesis. Khmelnytsk: Khmelnytsky National University [in Ukrainian].

19. Berezin, O. V. (2012). Ekonomichnyi potentsial ahrarnykh pidpryiemstv: mekhanizmy formuvannia ta rozvytku [The economic potential of agricultural enterprises: mechanisms of formation and development]. Poltava: Inter Hrafika [in Ukrainian].

20. Boniar, S. M., \& Aliabieva, O. M. (2019). Systematyzatsiia faktoriv vplyvu na innovatsiinyi rozvytok pidpryiemstva $\mathrm{v}$ suchasnykh ekonomichnykh umovakh [Systematization of factors influencing the innovative development of the enterprise in modern economic conditions]. Problemy ekonomiky - Problems of the economy, 3, 77-83 [in Ukrainian].

21. Krasnokutska, N. S., Bubenets, I. H., \& Chatchenko, O. Ye. (2015). Pidpryiemnytskyi potentsial yak faktor rozvytku torhovelnykh pidpryiemstv [Entrepreneurial potential as a factor in the development of commercial enterprises]. Kharkiv: Lider [in Ukrainian].

22. Herbych, L., \& Netrebchuk, L. (2020). Kredytospromozhnist silskohospodarskykh pidpryiemstv [Creditworthiness of agricultural enterprises]. Visnyk Kyivskoho natsionalnoho torhovelno-ekonomichnoho universytetu - Bulletin of Kyiv National University of Trade and Economics, 5, 88-101 [in Ukrainian]. 
23. Korsak, V. I. (2013). Faktory vplyvu na formuvannia rehionalnykh rozdribnykh merezh torhovykh zakladiv [Factors influencing the formation of regional retail chains of trade establishments]. Ahrosvit, 4, 45-51 [in Ukrainian].

24. Babyna, O. Ye. (2016). Metodoloho-praktychni osnovy formuvannia ta realizatsii potentsialu transportnykh pidpryiemstv [Methodological and practical bases of formation and realization of potential of transport enterprises]. Doctor's thesis. Kyiv: Kyiv State Academy of Water Transport named after Hetman Peter Konashevich-Sagaydachny [in Ukrainian].

25. Buhai, V. Z., Horbunova, A. V., \& Kliuieva, Yu.V. (2011). Teoretychni osnovy formuvannia potentsialu pidpryiemstva [Theoretical bases of formation of potential of the enterprise]. Visnyk Zaporizkoho natsionalnoho universytetu - Bulletin of Zaporizhia National University, 1(9). 27-33 [in Ukrainian].

The article submitted to editor's office on 09.08.2021.

Лой А., Блакита Г. Економічний потенціал підприємства торгівлі: структурний аспект.

Постановка проблеми. Виявлення та оцінка впливу факторів на розвиток економічного потенціалу допоможе створити механізм адаптації як до негативних, так і позитивних факторів середовища підприємства, щчо є основою ефективного управління ризиками, сприяє забезпеченню стабільності діяльності підприємства та визначенню можливостей для його розвитку.

Аналіз останніх досліджень $і$ публікацій. Проблемі визначення впливу факторів на економічний потенціал підприємства присвячено багато наукових праць, але для кожного підприємства сукупність факторів унікальна, тому їх можна порізному класифікувати, структурувати та оцінювати.

Метою статті є визначення та систематизація підходів до класифікації факторів впливу на економічний потенціал підприємства.

Матеріали та методи. Дослідження проведено із застосуванням методів теоретичного узагальнення, порівняння, аналізу та синтезу, щь дало змогу систематизувати існуючі теоретичні підходи до класифікації факторів впливу на економічний потенціал підприємства.

Результати дослідження. Фактори впливу поділяються на зовнішні, до яких належать усі, що пов'язані з діяльністю держави і суспільства, їх впливом на діяльність підприсмств і кон'юнктурою ринку, та внутрішні, щзо пов'язані з діяльністю підприємства і регулюються підприємством. Основне місце серед факторів зовнішнього середовища займають економічні, а інші види слід визначати та розглядати залежно від значущесті їх впливу та специфіки діяльності підприємства. Наукові погляди на структуру внутрішніх $і$ зовнішніх факторів дуже різні. Запропоновано поділяти фактори за рівнем виникнення на: індивідуальні, локальні, загальні та глобальні.

Висновки. Визначено та охарактеризовано специфіку взаємозв'язку різних факторів за: змістом, рівнем виникнення, ступенем впливу, контролем та представлено власне бачення структурування факторів залежно від рівня виникнення. потенціал.

Ключові слова: фактори, класифікація факторів, підприємство, економічний 